The Virtues of Uur Vices 



\section{The Virtues of Our Vices}

A Modest Defense of Cossip, Rudeness, and Other Bad Habits

\section{Emrys Westacott}

PRINCETON UNIVERSITY PRESS

Princeton and Oxford 
Copyright $\left({ }^{\circ} 2012\right.$ by Princeton University Press

Published by Princeton University Press, 4I William Street,

Princeton, New Jersey o 8540

In the United Kingdom: Princeton University Press, 6 Oxford Street,

Woodstock, Oxfordshire OX20 ITw

press.princeton.edu

All Rights Reserved

Library of Congress Cataloging-in-Publication Data

Westacott, Emrys.

The virtues of our vices : a modest defense of gossip, rudeness, and other bad habits / Emrys Westacott.

p. $\quad \mathrm{cm}$.

Includes bibliographical references and index.

ISBN 978-0-691-14199-2 (hardcover : alk. paper) I. Vices. 2. Conduct of life.

I. Title.

$\mathrm{BJ}_{1534} \cdot \mathrm{W}_{47} 2012$

179'.8- dc22 2011006595

British Library Cataloging-in-Publication Data is available

This book has been composed in Garamond Premier Pro and Raleigh Gothic

Printed on acid-free paper. $\infty$

Printed in the United States of America

10 98765432 I 
To Vicky 
